\title{
Flood Hazard Mapping Using Exploratory Regression Model in GIS Domain
}

\author{
Imran Ahmad ( $\nabla$ wonder_env@yahoo.com ) \\ Debre Tabor University \\ Assefa Fenta \\ Debre Tabor University \\ Mithas Dar \\ Integrated Watershed Management Program, R \& D, Panchayat Raj \\ Afera Halefom \\ Debre Tabor University \\ Aseret Tashome \\ Debre Tabor University \\ tesfa Andualem \\ Debre Tabor University
}

\section{Research Article}

Keywords: Awash basin, Flood hazard, GIS, Regression model

Posted Date: June 17th, 2021

DOI: https://doi.org/10.21203/rs.3.rs-604630/v1

License: (a) (1) This work is licensed under a Creative Commons Attribution 4.0 International License. Read Full License 


\section{Abstract}

In this study, attempt has been made to understand the spatial distribution of flood hazard and flood risk in the Awash basin, Ethiopia. Awash basin has been chosen because it's in continuous threat spatially and temporally. Eight determinant factors of flood hazard (viz., elevation, slope, rainfall, drainage density, landuse, soil type, wetness index and lineament density) were studied as independent variables. Each factor was reclassified into four classes and each was weighted according to its susceptibility towards the hazard. For example topographic lows were given the highest weight of 4 ; whereas topographic highs were given the lowest weight of 1 . All the independent variables were overlaid in GIS domain to get the final spatial distribution of hotspots of flood hazard. Exploratory regression analysis showed that the existing landuse is the dominant factor influencing the flood vulnerability. A total of 31 models were generated using Exploratory regression in GIS domain. Model number 31 was found to be the best fit model with the highest Adjusted $R^{2}$ value of 0.839539 and the least Akaike's Information criterion value of 1536.866 . Spatial autocorrelation tool run on the standard residuals yields the $Z$ score and $p$ value of 0.742522 and 0.457771 respectively; indicating that the residuals were neither clustered nor dispersed. Spatial extents of flood hazard and flood risk along with the priority for spatial planning in the Awash basin is digested well in this study.

\section{Introduction}

Flood being the spatial hazard demands the spatial planning to mitigate its risk (Dewan, 2013; Khailani and Perera, 2013). Spatial technology is the most appropriate technique to handle with the flood disaster risks which helps in decision making (Manfreda et al., 2011; Albano et al., 2014; Samela et al., 2017). Several scholars have studied flood and generated flood hazard and flood hazard risk maps for reducing the flood damage (Marchi et al., 2010; Wondim, 2016). Hazard zoning is also documented by several workers (Adedeji et al., 2012; Santato et al., 2013) for spatial planning processes.

However, in developing countries like Ethiopia, spatial planning is limited (Wapwera and Egbu, 2013). About $80 \%$ of the rains are received in three months (between June and September) in Ethiopia. Torrential rains are common in most parts of the country which leads to flooding to the settlements in the topographic lows (Chibssa, 2007; Dessie and Tadesse, 2013; Getahun and Gebre, 2015). For long term disaster management and mitigation, geospatial technique is the most appropriate tool (Steinberg and Lindfield, 2012; Watson and Agbola, 2013; UNDP, 2015).

The paper focuses on flood inundation analyses in Awash basin, Ethiopia. According to Tsay (2013) flooding in the Awash River Basin is mainly due to seasonal rainfall which is of great concern. The Awash River flooding causes expansion of its floodplains and inundation of topographic lows and causes severe damages to the settlements (Abebe, 2007). The Awash basin is under the continuous threat varying in extents spatially and temporally. Coenraads (2005) testified that the Awash River Basin is flooded for short durations at upstream but the downstream remain inundated for months every year during the wet season which influences the crop production on flood plains. According to IPCC (2007), the magnitude and frequency of floods may be compounded by climate change. As scholars have documented the increment 
of flashfloods in entire Ethiopia (Paolo et al., 2013), hence the flood hazard mapping in Ethiopia especially the Awash basin becomes the need of an hour for decision making processes.

\section{Study Area}

The Awash basin located in the rift valley of the Ethiopia is chosen for flood hazard mapping. The elevation of the Awash basin ranges from 362.5 to $2,989.64 \mathrm{~m}$ above mean sea level (Fig. 1). The study area is rugged and undulating with slopes varying from 0 to 46.38 degrees. The mean annual rainfall in the study area varies from about 178.67-461.13 mmyr $^{-1}$ at Dubti, Tendaho and Mile towns in the northeast to 1170.41-1452.86 $\mathrm{mmyr}^{-1}$ at Holota and Ginchi towns in southwest the study area. The lowlands of the Afar region comprise the major part of the Awash basin. The Awash river rises at southwest of the basin (near Ginchi town) flows along the rift valley and finally drains in the Lake Abbe situated at the north of the basin. The total length of the river is $1202.01 \mathrm{~km}$. The river drains about $112244.88 \mathrm{~km}^{2}$ of land with the perimeter of $1994.4 \mathrm{~km}$. The climate of the Awash basin is partly influenced by the movement of the InterTropical Convergence Zone (ITCZ) and partly by Indian monsoon (Romill, 2010).

The main objective of this study is to analyze the spatial distribution of flood hazard, flood risk and evaluate the influence of various factors towards the inundation of topographic lows in the Awash basin using ArcGIS 10.3.1 plateform.

\section{Methodology}

A total of eight determinant factors of flood hazard potential (viz., elevation, slope, rainfall, drainage density, landuse, soil type, topographic compound index and lineament density) has been studied and analyzed in GIS domain. Missing or no value data in the factors were computed using kriging interpolation technique. We choose the major semi axis and minor semi axis as 118661.1 and 111161.1 respectively along with the tolerance of 45 to accommodate the maximum neighborhood. The unknown value was determined by at least 18 neighboring values with different weights. Each factor has been given weightage from 1-5 scale (1, Very low hazard; 5; Very high hazard potential). These factors were overlaid in GIS domain to generate the flood vulnerability map of the study area. Exploratory regression analysis has been done to analyze the influence of each factor towards the flood hazard vulnerability. Autocorrelation (Moran's I) tool was run to check if the standard residuals are normally distributed. Furthermore, flood hazard map has been overlaid on population of the study area map to generate the flood risk map for better spatial planning. The overall methodology used in this study is shown in Fig. 2.

\section{Results}

Determinant factors

Elevation and slope

The movement and direction of the flood is controlled by elevation of the terrain (Gigovi'c et al., 2017). The elevation of the study area varying from 362.5-2,989.64 m has been reclassified into five classes. 
Topographic lows (362.5-960.04 m) were found to cover $34.41 \%$ of the total area of the Awash basin. The topographic highs $(2,309.68-2,989.64 \mathrm{~m})$ were found to cover only $7.25 \%$ of the study area. Each class has been given weightage depending on its vulnerability towards flood. Low laying areas (for example 362.5$960.04 \mathrm{~m}$ has been given the highest weight of 5 as these areas are more vulnerable to flood; whereas areas at the highest elevation of 2,309.68-2,989.64 $\mathrm{m}$ has been given the lowest weightage of 1 as such areas are the least vulnerable towards flooding. The weighted map of the elevation is shown in Fig. 3. Slope is another determinant factor for flood occurrence. The slope of the study area ranging from $0-46.38^{0}$ have been reclassified into five classes. Flat to gentle slopes are more vulnerable to overland flow accumulation compared to steep slopes. Most of the study area (49.32\%) is underlain by flat to gentle slopes $\left(0-4.06^{0}\right)$. Flat to gentle slopes $\left(0-4.06^{\circ}\right)$ has been assigned the highest weightage of 5 , as such slopes are more vulnerable towards flooding. Whereas steep slopes $\left(20.28-46.38^{\circ}\right)$ has been given the flood potential value of 1 because such slopes are the least vulnerable towards flooding. The weighted map of the slope is shown in Fig. 3.

Rainfall and drainage density

The rainfall (178.67-1452.86 $\mathrm{m}$ ) is another important factor determining the flood vulnerability. The highest rainfall $(1170.41-1452.86 \mathrm{~mm}$ ) was found to cover $13.58 \%$ of the study area and the lowest rainfall $(178.67-461.13 \mathrm{~mm})$ was found to cover $26.65 \%$ of the area. More rainfall in any area means more proneness to floods (Guo et al., 2014). Accordingly suitable weightages have been given to different rainfall classes depending on their potential towards flood. For example, rainfall ranging between 178.67-461.13 $\mathrm{mm}$ was assigned the least weight of 1 , whereas, rainfall ranging between $1170.41-1452.86 \mathrm{~mm}$ was assigned the highest weight of 5. The weighted rainfall map is shown in Fig. 4. The drainage density of the area ranges from 0.08 to $9.56 \mathrm{~km} / \mathrm{km}^{2}$. About $22.08 \%$ of the area is underlain by the highest Dd values (5$9.56 \mathrm{~km} / \mathrm{km}^{2}$ ). Drainage densities of the study area have been reclassified according to their flood hazard potential. Drainage density of the range $5-9.56 \mathrm{~km} / \mathrm{km}^{2}$ is the highest contributor towards flood and hence the highest weightage of 5 has been given. Whereas, drainage density of $0.08-1.16 \mathrm{~km} / \mathrm{km}^{2}$ have been given the lowest weightage of 1 because low drainage densities are generally located at the high elevations. The weighted drainage density map is shown in the Fig. 4.

Landuse and soils

Water bodies, settlements, and wetlands were found to cover $1.29 \%$ of the total study area. The computed areal extent of forest, woodland, and afro alpine is $3.67 \%$. The landuse map of the study area was analyzed with respect to the flood vulnerability. Accordingly suitable weightages have been given to the different landuse classes. For example, forest, woodland, and afro alpine landuse classes were given the least potential of 1 . Whereas, landuse classes like water bodies, wetlands, and settlements has been assigned the highest weightage of 1. Landuse classes like bare land and urban land were given the weightage of 4 and landuse classes like cultivation land; and grassland were assigned a weightage of 3 . The weighted landuse map is depicted in the Fig. 5. Different soils have different infiltration rates, permeability, and porosity. The soil characteristics define their potential with regard to flood potential (Rimba et al., 2017). Therefore, suitable weightages have been given to different soil types of the study area. Pellic and chromic vertisols 
have been given the highest weightages of 5 indicating their highest contribution towards flood due to their low infiltration rates. Conversely, chromic cambisols, eutric nitisols have been assigned the least weight of 1 due to their least susceptibility towards flooding. The weighted soil map of the study area is shown in the Fig. 5.

\section{Topography index and Lineament density}

Compound topography index (CTI) of the study area has been computed in the GIS domain. CTI values of the study area varies from -0.02 to 8 . The areas underlain by the highest CTI values (1.46-8) were computed to be $24.03 \%$ of the total area. Areas with the higher value of CTI have higher wetland potential compared to the areas with lower CTI values. Therefore, the highest weightage of 5 has been given to the areas with CTI values of 1.46- 8. Whereas, areas with the lowest CTI values of $-0.02--0.16$ were assigned the lowest weightage of 1 due to their lowest wetland potential. The weighted CTI map is shown in the Fig. 6.

Lineament density $(\mathrm{Ld})$ of the study area has been calculated using GIS. Ld of the study area varies from $6.81-0.43 \mathrm{~km} / \mathrm{km}^{2}$. Areas with higher Ld values have more channels to infiltrate water downwards.

Therefore areas with the highest $L d$ values $\left(6.81-12.91 \mathrm{~km} / \mathrm{km}^{2}\right)$ were assigned the lowest weightage of 1 . Whereas, areas underlain by lowest $L d$ values $(0.16-0.43)$ were assigned the highest weightage of 5 . The weighted map of the Ld is shown in the Fig. 6.

Flood hazard and flood risk

Each factor was reclassified into five classes and weightages have been given to each class in GIS domain (Table 1). All the weighted factors were allowed to overlay in GIS domain to get the flood hazard map. Flood vulnerability raster map have been reclassified into 5 classes viz., Very low (1), Low (2), Moderate (3), High (4) and Very high (5) hazards. The areal extent of very low, low, moderate, high and very high flood zones area $6.96,10.21,33.09,38.28$ and $11.46 \mathrm{~km}^{2}$ respectively. 
Table 1

Thematic layers, their areal extent along with their potential values and the associated hazard

\begin{tabular}{|c|c|c|c|c|}
\hline Theme & Classes & Area (\%) & Potential value & Hazard \\
\hline \multirow[t]{5}{*}{ Elevation } & $2,309.68-2,989.64$ & 7.25 & 1 & Very high \\
\hline & $1,938.79-2,309.67$ & 15.90 & 2 & High \\
\hline & $1,506.09-1,938.78$ & 18.68 & 3 & Moderate \\
\hline & $960.05-1,506.08$ & 23.76 & 4 & Low \\
\hline & $362.5-960.04$ & 34.41 & 5 & Very low \\
\hline \multirow[t]{5}{*}{ Slope } & $0-4.06$ & 49.32 & 5 & Very high \\
\hline & $4.07-6.36$ & 31.05 & 4 & High \\
\hline & $6.37-10.11$ & 13.09 & 3 & Moderate \\
\hline & $10.12-20.27$ & 5.21 & 2 & Low \\
\hline & $20.28-46.38$ & 1.34 & 1 & Very low \\
\hline \multirow[t]{5}{*}{ Rainfall } & $178.67-461.13$ & 26.65 & 1 & Very low \\
\hline & $461.14-707.94$ & 22.89 & 2 & Low \\
\hline & $707.95-923.59$ & 17.93 & 3 & Moderate \\
\hline & $923.6-1170.4$ & 18.95 & 4 & High \\
\hline & $1170.41-1452.86$ & 13.58 & 5 & Very high \\
\hline \multirow[t]{5}{*}{ Drainage density } & $0.08-1.16$ & 2.60 & 1 & Very low \\
\hline & $1.17-1.69$ & 11.68 & 2 & Low \\
\hline & $1.7-2.77$ & 25.12 & 3 & Moderate \\
\hline & $2.78-4.99$ & 38.51 & 4 & High \\
\hline & $5-9.56$ & 22.08 & 5 & Very high \\
\hline \multirow[t]{5}{*}{ Land-use } & Forest, Woodland, Afro alpine & 3.67 & 1 & Very low \\
\hline & Grassland, Shrub land, Plantation & 40.64 & 2 & Low \\
\hline & Cultivation land & 21.70 & 3 & Moderate \\
\hline & Bare land, Urban land & 32.70 & 4 & High \\
\hline & Water bodies, Settlements, Wetland & 1.29 & 5 & Very high \\
\hline \multirow[t]{2}{*}{ Soils } & Chromic cambisols, Eutric nitisols & 21.43 & 1 & Very low \\
\hline & Calcaric regosols & 36.76 & 2 & Low \\
\hline
\end{tabular}




\begin{tabular}{|lllll|}
\hline Theme & Classes & Area (\%) & Potential value & Hazard \\
\hline & Lithosols & 5.37 & 3 & Moderate \\
\cline { 2 - 5 } & Fluvisols, Yermisols & 3.44 & 4 & High \\
\cline { 2 - 5 } Topography index & Pellic and chromic vertisols & 32.99 & 5 & Very high \\
\cline { 2 - 5 } & $-0.02--0.16$ & 10.54 & 1 & Very low \\
\cline { 2 - 5 } & $-0.17-0.19$ & 8.72 & 2 & Low \\
\hline $0.2-0.37$ & 22.33 & 3 & Moderate \\
\hline $0.38-1.45$ & 34.38 & 4 & High \\
\hline $1.46-8$ & 24.03 & 5 & Very high \\
\hline Lineament density & $6.81-12.91$ & 3.35 & 1 & Very low \\
\cline { 2 - 5 } & $0.44-1.49$ & 6.09 & 2 & Low \\
\hline $1.5-3.39$ & 13.49 & 3 & Moderate \\
\hline $0.44-1.49$ & 30.62 & 4 & High \\
\hline $0.16-0.43$ & 46.44 & 5 & Very high \\
\hline
\end{tabular}

For computing the flood risk map, flood vulnerability map was overlaid with weighted map of population distribution and landuse map. The output flood risk map was prioritized accordingly to get a clear picture about which areas should be given preferences for flood management processes. The flood vulnerability and flood risk map is shown in Fig. 7. Areas such as Adi Gala, Asbuli, Gewane, Loqiya, Weranso, and Mile have been found in the highest flood vulnerability zone; hence these areas are kept in the first priority for management process. Whereas, towns such as Alem Gena, Sendafa, Gina Ager, Ankober, Assagirt, Aliyu Amba, Debre Sina, Armanaya, Jimate, Ancharo, Karakore, Kombolcha, Boru, Wirgesa, Sirinka, Kobo, Hurso, Gota, and Teferi Ber fall in "very low" flood hazard; hence were giving the least priority for flood management process. The areal extent of each flood hazard zone along with the towns associated and their priority is shown in Table 2. 
Table 2

Areal extent of flood vulnerability in the Awash basin, Ethiopia

\begin{tabular}{|c|c|c|c|c|}
\hline $\begin{array}{l}\text { Flood } \\
\text { hazard }\end{array}$ & $\begin{array}{l}\text { Area } \\
\left(\mathrm{Km}^{2}\right)\end{array}$ & Percent & Representative towns & *Priority \\
\hline Very low & 7777.28 & 6.96 & $\begin{array}{l}\text { Alem Gena, Sendafa, Gina Ager, Ankober, Assagirt, Aliyu } \\
\text { Amba, Debre Sina, Armanaya, Jimate, Ancharo, } \\
\text { Karakore, Kombolcha, Boru, Wirgesa, Sirinka, Kobo, } \\
\text { Hurso, Gota, and Teferi Ber }\end{array}$ & 5 \\
\hline Low & 11414.23 & 10.21 & $\begin{array}{l}\text { Bantu, Melka Kunture, Dukem, Debre Zeyt, Enjere, } \\
\text { Holota, Iteya, Sire, Angada, Balchi, Koremas, Chelekko, } \\
\text { Meteh Bela, Arba Reketi, Kersa, Arabi, Gogli, Mersa, } \\
\text { Hayk, and Kemise. }\end{array}$ & 4 \\
\hline Moderate & 36975.46 & 33.09 & $\begin{array}{l}\text { Harbu, Bati, Mekoy, Shewa Robit, Debel, Dulecha, } \\
\text { Metehara, Lemen, Kondaliti, Arboye, Wolonkomi, Bike, } \\
\text { Shinili, Dire Dawa, Dehabo, Wenji, Nazeret, Sodore, Alem } \\
\text { Tena, and Ambosa }\end{array}$ & 3 \\
\hline High & 42773.32 & 38.28 & $\begin{array}{l}\text { Harawa, Aydora, Dubti, Melka Werer, Awash, Koka, and } \\
\text { Tendaho }\end{array}$ & 2 \\
\hline Very high & 12801.18 & 11.46 & Adi Gala, Asbuli, Gewane, Loqiya, Weranso, and Mile & 1 \\
\hline
\end{tabular}


Table 3

Explanatory regression models

\begin{tabular}{|c|c|c|c|c|c|c|c|c|c|c|}
\hline Model & $A d j R^{2}$ & AICc & $\mathrm{JB}$ & K-BP & MaxVIF & $\mathrm{X} 1$ & $\mathrm{X} 2$ & $\mathrm{X} 3$ & $X 4$ & $\mathrm{X} 5$ \\
\hline 1 & 0.3762 & 1913.932 & 0.152 & 0.412 & 1.000 & $\mathrm{Rf}$ & & & & \\
\hline 2 & 0.035779 & 2216.597 & 0.174 & 0.496 & 1.000 & $\mathrm{Dd}$ & & & & \\
\hline 3 & 0.41192 & 1872.95 & 0.132 & 0.008 & 1.000 & Lc & & & & \\
\hline 4 & 0.104506 & 2165.205 & 0.144 & 0.102 & 1.000 & Ld & & & & \\
\hline 5 & 0.062832 & 1873.78 & 0.167 & 0.232 & 1.000 & $\mathrm{Cti}$ & & & & \\
\hline 6 & 0.314543 & 1979.439 & 0.165 & 0.109 & 1.000 & Elev & & & & \\
\hline 7 & 0.05857 & 2199.972 & 0.199 & 0.090 & 1.000 & SIp & & & & \\
\hline 8 & 0.379233 & 1911.564 & 0.188 & 0.477 & 1.199 & $\mathrm{Rf}$ & $\mathrm{Dd}$ & & & \\
\hline 9 & 0.621215 & 1568.243 & 0.183 & 0.008 & 1.078 & $\mathrm{Rf}$ & Lc & & & \\
\hline 10 & 0.383913 & 1906.304 & 0.196 & 0.137 & 1.180 & $\mathrm{Rf}$ & $\mathrm{Ld}$ & & & \\
\hline 11 & 0.439723 & 1840.309 & 0.197 & 0.070 & 1.001 & $\mathrm{Dd}$ & Lc & & & \\
\hline 12 & 0.128952 & 2146.988 & 0.186 & 0.002 & 1.011 & $\mathrm{Dd}$ & $\mathrm{Ld}$ & & & \\
\hline 13 & 0.318867 & 1976.061 & 0.193 & 0.090 & 1.266 & $\mathrm{Dd}$ & Elev & & & \\
\hline 14 & 0.076497 & 2187.63 & 0.171 & 0.073 & 1.060 & $\mathrm{Dd}$ & Slp & & & \\
\hline 15 & 0.47169 & 1799.479 & 0.171 & 0.089 & 1.016 & Lc & Ld & & & \\
\hline 16 & 0.614277 & 1580.857 & 0.151 & 0.076 & 1.036 & Lc & Elev & & & \\
\hline 17 & 0.424097 & 1859.427 & 0.192 & 0.080 & 1.045 & Lc & Slp & & & \\
\hline 18 & 0.341823 & 1952.234 & 0.199 & 0.065 & 1.094 & Ld & Elev & & & \\
\hline 19 & 0.238 & 1953.543 & 0.178 & 0.048 & 1.012 & Ld & Cti & & & \\
\hline 20 & 0.126371 & 2149.045 & 0.149 & 0.078 & 1.105 & Ld & Slp & & & \\
\hline 21 & 0.627226 & 1558.149 & 0.192 & 0.083 & 1.253 & $\mathrm{Rf}$ & Lc & Ld & & \\
\hline 22 & 0.628398 & 1555.961 & 0.192 & 0.471 & 2.659 & $\mathrm{Rf}$ & Lc & Elev & & \\
\hline 23 & 0.492162 & 1773.036 & 0.188 & 0.453 & 1.026 & $\mathrm{Dd}$ & Lc & Ld & & \\
\hline 24 & 0.444778 & 1835.035 & 0.192 & 0.347 & 1.106 & $\mathrm{Dd}$ & Lc & SIp & & \\
\hline 25 & 0.345323 & 1949.552 & 0.193 & 0.479 & 1.372 & $\mathrm{Dd}$ & $\mathrm{Ld}$ & Elev & & \\
\hline 26 & 0.14216 & 2137.393 & 0.181 & 0.387 & 1.160 & $\mathrm{Dd}$ & $\mathrm{Ld}$ & SIp & & \\
\hline 27 & 0.629715 & 1553.492 & 0.299 & 0.451 & 1.122 & Lc & $\mathrm{Ld}$ & Elev & & \\
\hline
\end{tabular}




\begin{tabular}{|llllllllllll|}
\hline Model & AdjR & AlCc & JB & K-BP & MaxVIF & X1 & X2 & X3 & X4 & X5 & \\
\hline 28 & 0.5432 & 1544.362 & 0.289 & 0.442 & 1.134 & Lc & Ld & Cti & & \\
\hline 29 & 0.636866 & 1540.968 & 0.382 & 0.441 & 2.204 & Rf & Lc & Elev & & & \\
30 & 0.732728 & 1548.844 & 0.398 & 0.498 & 1.222 & Lc & Ld & Elev & Slp & & \\
\hline $\mathbf{3 1}$ & $\mathbf{0 . 8 3 9 5 3 9}$ & $\mathbf{1 5 3 6 . 8 6 6}$ & 0.432 & 0.421 & 2.353 & Rf & Lc & Ld & Elev & Slp & Cti \\
\hline
\end{tabular}

Where AdjR ${ }^{2}$, Adjusted R squared ${ }^{1}$; AICc, Akaike's Information criterion ${ }^{1}$; JB; Jarque- Bera statistic ${ }^{2}$; K-BP, Koenker (BP) statistic ${ }^{3}$; MaxVIF, Maximum Variance Inflation ${ }^{4} ; \mathrm{X}$, variables

${ }^{1}$ Measures of model performance

${ }^{2}$ When this test is statistically significant $(p<0.01)$ model predictions are biased (the residuals are not normally distributed)

${ }^{3}$ When this test is statistically significant $(p<0.01)$, the relationships modeled are not consistent (either due to non-stationarity or heteroskedasticity).

${ }^{4}$ Large VIF (> 7.5, for example) indicates explanatory variable redundancy.

Rf, Rainfall; Dd, Drainage density, Lc, Landcover; Ld, Lineament density, Elev, Elevation; Slp, Slope; Cti, Compound topography index.

\section{Discussion}

All the thematic layers have been weighted in accordance with their susceptibility towards erosion in GIS domain. It is clear from the flood vulnerability and flood risk map that areas under threat mostly exist in the northeastern part of the study area which exists in topographic lows. Different determinant factors may influence differently towards the flood susceptibility. In order to understand the influence of various determinant factors towards the hotspots of flood hazard potential, exploratory regression analysis was done in GIS domain. Before running the exploratory regression, correlations between the variables have to done to exclude any variable with collinearity or redundancy. Hence seven factors (viz., rainfall, drainage density, landuse, lineament density, elevation, slope and compound topography) were selected out of nine factors. Among the seven factors, the highest value for adjusted $R^{2}(0.41192)$ was shown by landuse followed by rainfall $(0.3762)$, elevation $(0.314543)$, lineament density $(0.104506)$, topography index (0.062832), slope (0.05857) and drainage density (0.035779). It can be inferred that the existing landuse of the study area is the dominant factor influencing the flood hazard, while as, drainage density is not affecting much toward flood hazard. Therefore, shifting cultivation in the study area by just one unit may lead to increment in the hazard by $41.11 \%$. All the seven factors showed statistically insignificant Koenker (BP) values $(p>0.005)$. Among the seven factors, the best fit factor observed is landuse reflected by its least Akaike's Information criterion value of 1872.95. A total of 31 models were generated by combing the individual factors differently to find the best model fit. There is no Exploratory variable redundancy in all the models as observed by their maximum variance inflation values $(<7)$. Furthermore Koenker (BP) statistic is 
statistically insignificant $(p>0.005)$ in all the models. Among all the 31 models, model number 31 was found to be the best model fit as reflected by its lowest Akaike's Information criterion value of 1536.866 (Table 2). In the model number 31, drainage density factor was omitted as it didn't contribute much towards the model.

After doing regression modeling, it's imperative to check if the standard residuals are normally distributed. If the standard residuals are clustered or dispersed, it implies the model is biased or invalid. Hence, spatial autocorrelation tool (Moran's I) was run on the standard residuals. The standard residuals were found to be distributed randomly (Fig. 7). The Moran's index value of 0.0219 was obtained with its $Z$ score and $p$ value of 0.742522 and 0.457771 respectively.

\section{Conclusion}

A total of eight determinant factors were chosen to study the hotspots of flood hazard in the Awash basin, Ethiopia. Each factor was weighted according to their flood potential. All the weighted factors were overlaid to get the spatial maps of flood hazard and flood risk. The areal extents of very low, low, moderate, high, and very high hazard zones are $6.96,10.21,33.09,38.28$ and $11.46 \mathrm{~km}^{2}$ respectively. The output map depicts that northeast part of the study area exists in the "very high" flood potential as well as flood risk zone; therefore demands the first priority for spatial planning. Priority table has been generated to highlight the areas demanding the highest and the lowest priority. Exploratory regression clearly showed that the existing landuse is the dominant factor influencing the flood potential. Spatial autocorrelation tool showed the random distribution of the standard residuals; hence validating the model. This study proved the efficiency of exploratory regression model to be the best technique to understand the impact of various determinant thematic layers towards the mapping of flood hazard and flood risk and can be applied at continental level with some modification.

\section{References}

1. Abebe FC (2007) Flood hazard assessment using GIS in Bacho plain, Upper Awash Valley, south west of Addiss Ababa. M.Sc thesis, Addis Ababa University, Addis Ababa

2. Adedeji $\mathrm{OH}$, Odufuwa BO, Adebayo $\mathrm{OH}$ (2012) Building capabilities for flood disaster and hazard preparedness and risk reduction in Nigeria: need for spatial planning and land management. $\mathrm{J}$ Sustainable Dev Africa 14(1):45-58

3. Albano R, Sole A, Adamowski J, Mancusi L (2014) A GIS-based model to estimate flood consequences and the degree of accessibility and operability of strategic emergency response structures in urban areas. Nat Hazards Earth Syst Sci Discuss 14:2847-2865

4. Chibssa AF (2007) Flood Hazard Assessment Using GIS in Bacho Plain, Upper Awash Valley, Southwest of Addis Ababa. Master of Science Thesis. Addis Ababa University, Addis Ababa

5. Coenraads N (2005) Flood Recession Farming: An Overview and Case Study from the Upper Awash Catchment, Ethiopia. Masters thesis 
6. Dessie G, Tadesse M, 2013. Rethinking forestry and natural resources higher education in Ethiopia: an education for sustainable development perspective. South. Afr. J. Environ. Educ. 29, 216-244. Ogato GS et al. Journal of Hydrology: Regional Studies 27 (2020)

7. Dewan AM (2013) Floods in a Megacity: Geospatial Techniques in Assessing Hazards, Risk and Vulnerability. Springer Dordrecht and Springer Heidelberg, New York

8. Gigovi'c L, Pamu `car D, Baji'c Z, Drobnjak S (2017) Application of GIS-Interval rough AHP methodology for flood hazard mapping in urban areas. Water 9(360):1-26

9. Getahun YS, Gebre SL (2015) Flood hazard assessment and mapping of flood inundation area of the Awash River Basin in Ethiopia using GIS and HEC-GeoRAS/ HEC-RAS model. J Civil Environ Eng 5(4):112

10. Guo E, Zhang J, Ren X, Zhang Q, Sun Z (2014) Integrated risk assessment of flood disaster based on improved set pair analysis and the variable fuzzy set theory in central Liaoning Province. China Nat Hazards 74:947-965

11. Khailani DK, Perera R (2013) Mainstreaming disaster resilience attributes in local development plans for the adaptation to climate change induced flooding: A study based on the local plan of Shah Alam City, Malaysia. Land Use Policy 30:615-627

12. Manfreda S, Di Leo M, Sole A (2011) Detection of flood-prone areas using digital elevation models. J Hydrol Eng 16:781-790

13. Marchi L, Borga M, Preciso E, Gaume E (2010) Characterization of selected extreme flash floods in Europe and implications for flood risk management. J Hydrol (Amst) 394:118-133

14. Paolo B, Yonas T, Rossano C (2013) The increased frequency of flash floods in Ethiopia: climate change or human impact. Geophys Res Abstracts

15. Rimba AB, Setiawati MD, Sambah AB, Miura F (2017) Physical Flood Vulnerability Mapping Applying Geospatial Techniques in Okazaki City, Aichi Prefecture, Japan. Urban Sci 1(7):1-22

16. Romilly G (2010) Evaluation of satellite rainfall estimates over Ethiopian river basins. Hydrol Earth Syst Sci 15:1505-1514

17. Samela C, Troy TJ, Manfreda S (2017) Geomorphic Classifiers for flood-prone areas delineation for data-scarce environments. AdvWater Resour 102:13-28

18. Santato S, Bender S, Schaller M (2013) The European Floods Directive and Opportunities Offered by Land Use Planning. CSC Report 12. Climate Service Center., Germany

19. Steinberg F, Lindfield M (2012) Spatial development and technologies for Green cities. In: Lindfield M, Steinberg F (eds) 2012. Green Cities. Asian Development Bank, Mandaluyong City

20. Tsay L (2013) Flooding Vulnerability Assessment - A Case Study of Hou-Jing Stream in Taiwan. Mediterranean J Social Sci

21. UNDP (2015) Strengthening Disaster Risk Governance: UNDP Support During the HFA Implementation Period 2005-2015. UNDP, New York

22. Wapwera SD, Egbu CO (2013) Master Planning System: Constraints for Planning Authorities in Jos Metropolis. Nigeria The Built Human Environment Review 6:61-81 
23. Watson V, Agbola B (2013) Who Will Plan Africa's Cities? The Counterpoints Series. Africa Research Institute., London

24. Wondim YK (2016) Flood Hazard and Risk Assessment Using GIS and Remote Sensing in Lower Awash Sub-basin. Ethiopia Journal of Environment Earth Science 6(9):69-86

\section{Figures}

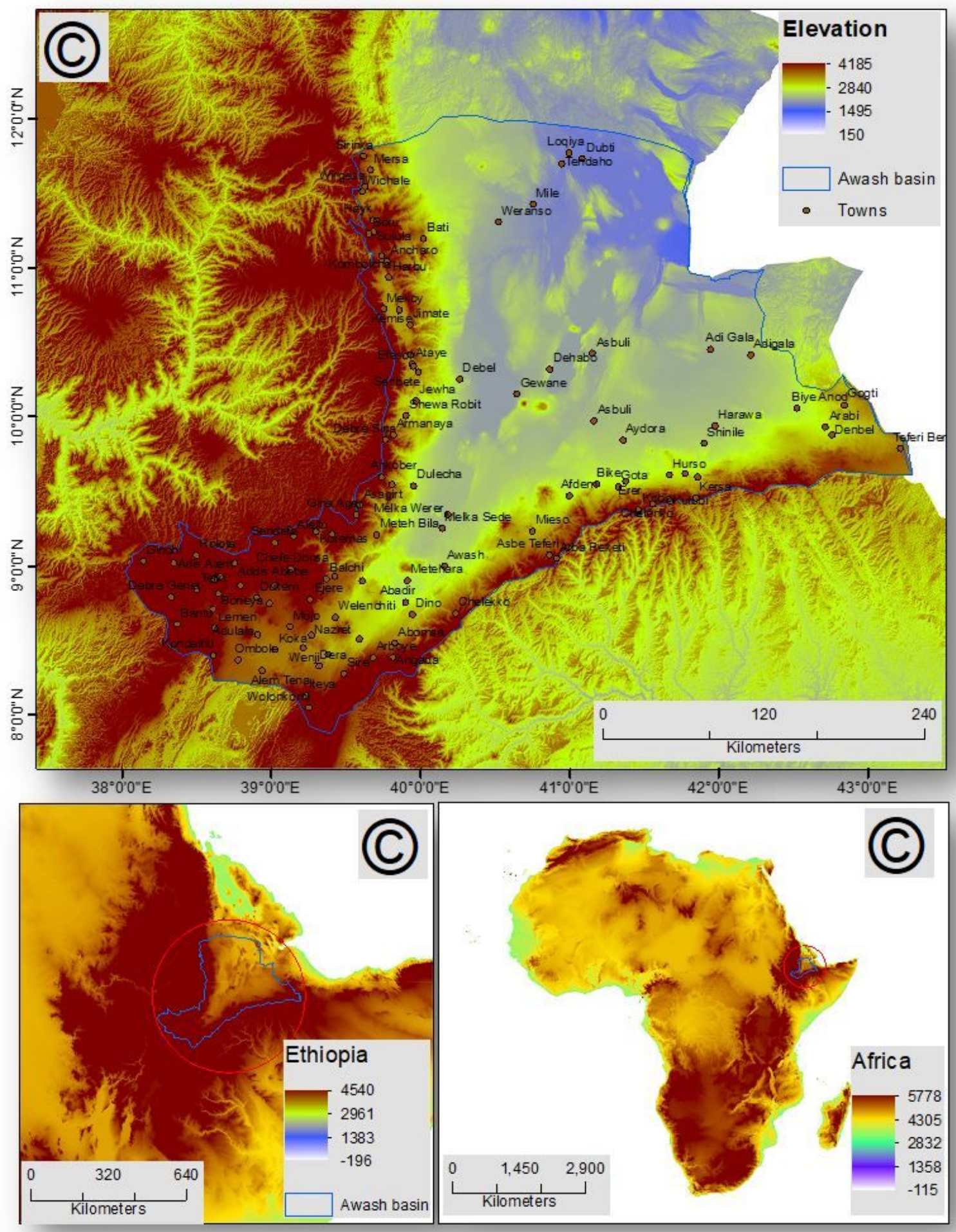




\section{Figure 1}

Location of the Awash basin, Ethiopia. Note: The designations employed and the presentation of the material on this map do not imply the expression of any opinion whatsoever on the part of Research Square concerning the legal status of any country, territory, city or area or of its authorities, or concerning the delimitation of its frontiers or boundaries. This map has been provided by the authors.

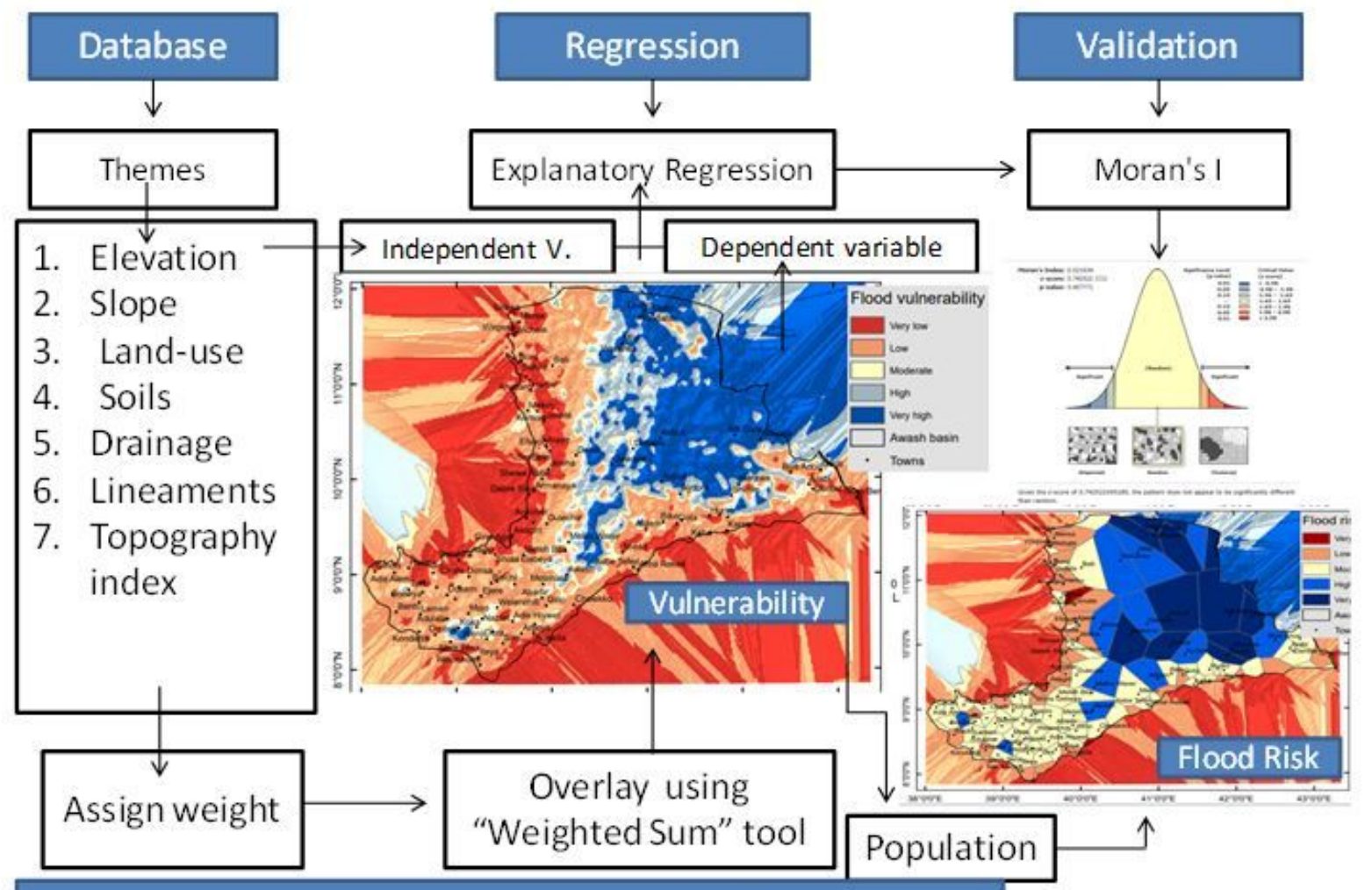

Flood vulnerability Overlaid on Population distribution \& Landuse= Flood risk

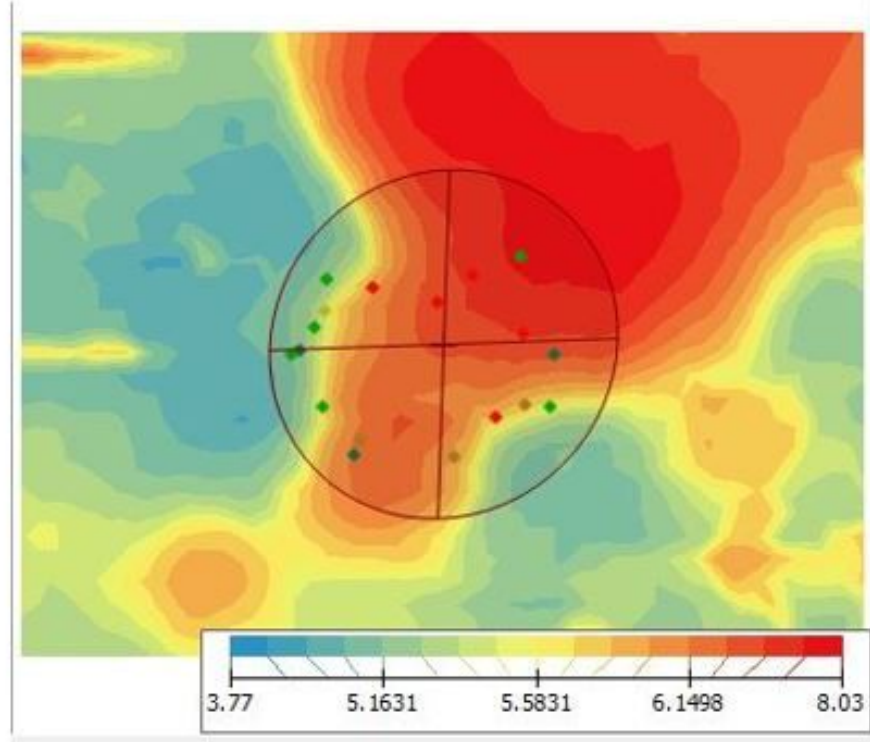

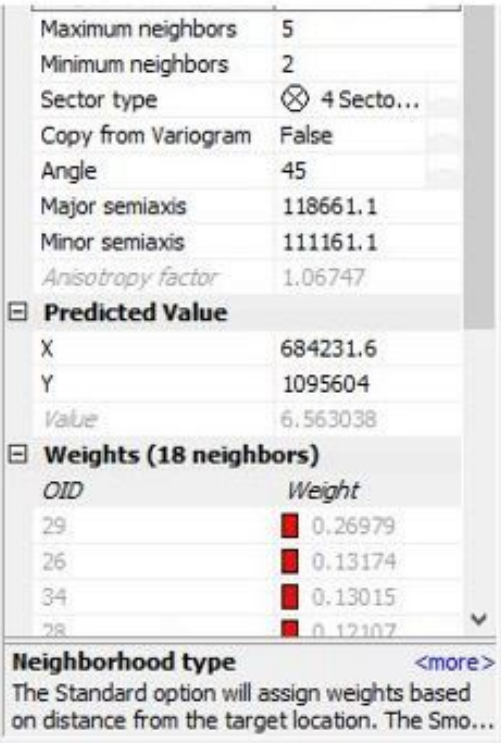

Figure 2 
Methodology employed Note: The designations employed and the presentation of the material on this map do not imply the expression of any opinion whatsoever on the part of Research Square concerning the legal status of any country, territory, city or area or of its authorities, or concerning the delimitation of its frontiers or boundaries. This map has been provided by the authors.

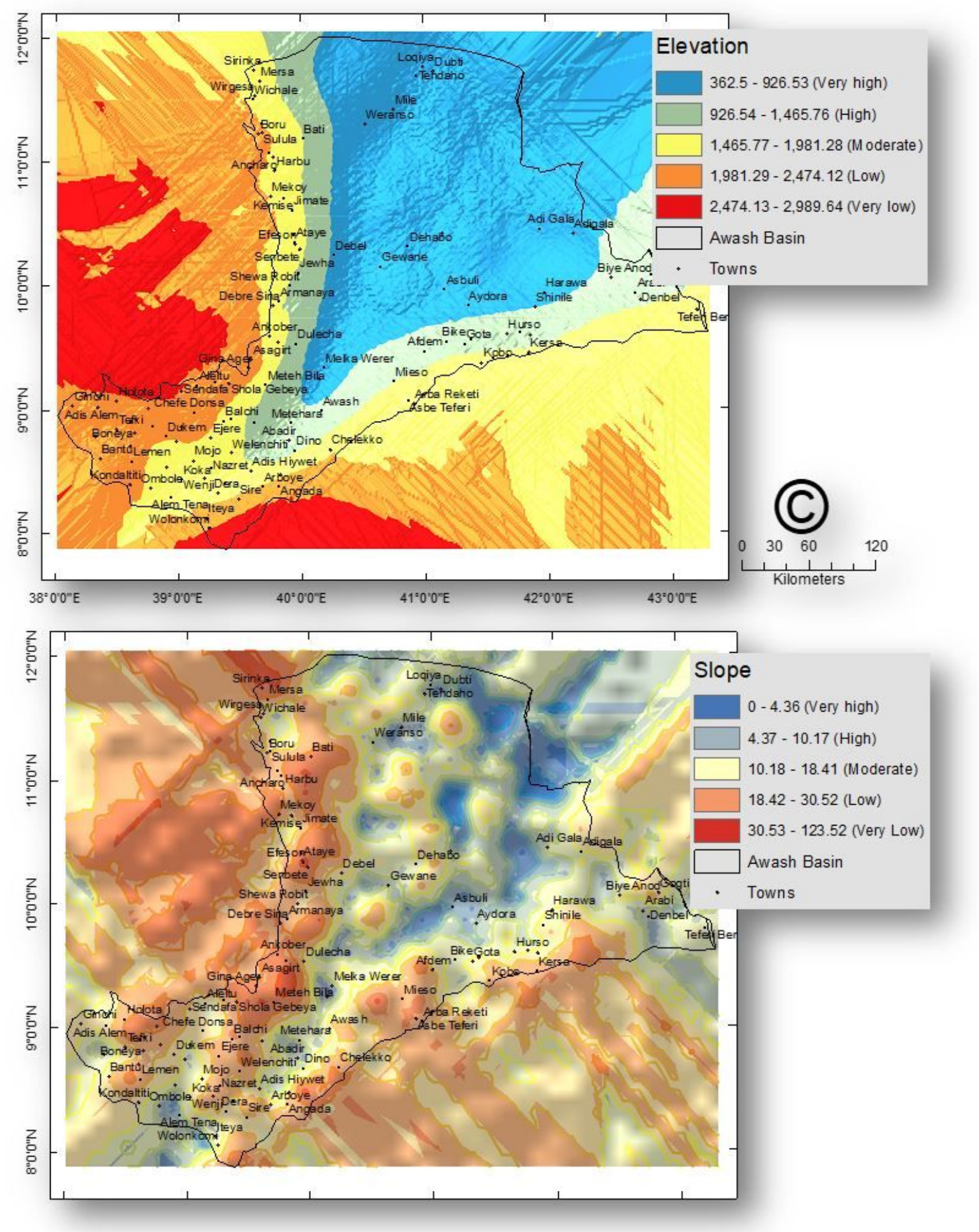

\section{Figure 3}

Weighted layers of elevation (meters) and Slope (degrees) of the Awash basin, Ethiopia Note: The designations employed and the presentation of the material on this map do not imply the expression of any 
opinion whatsoever on the part of Research Square concerning the legal status of any country, territory, city or area or of its authorities, or concerning the delimitation of its frontiers or boundaries. This map has been provided by the authors.
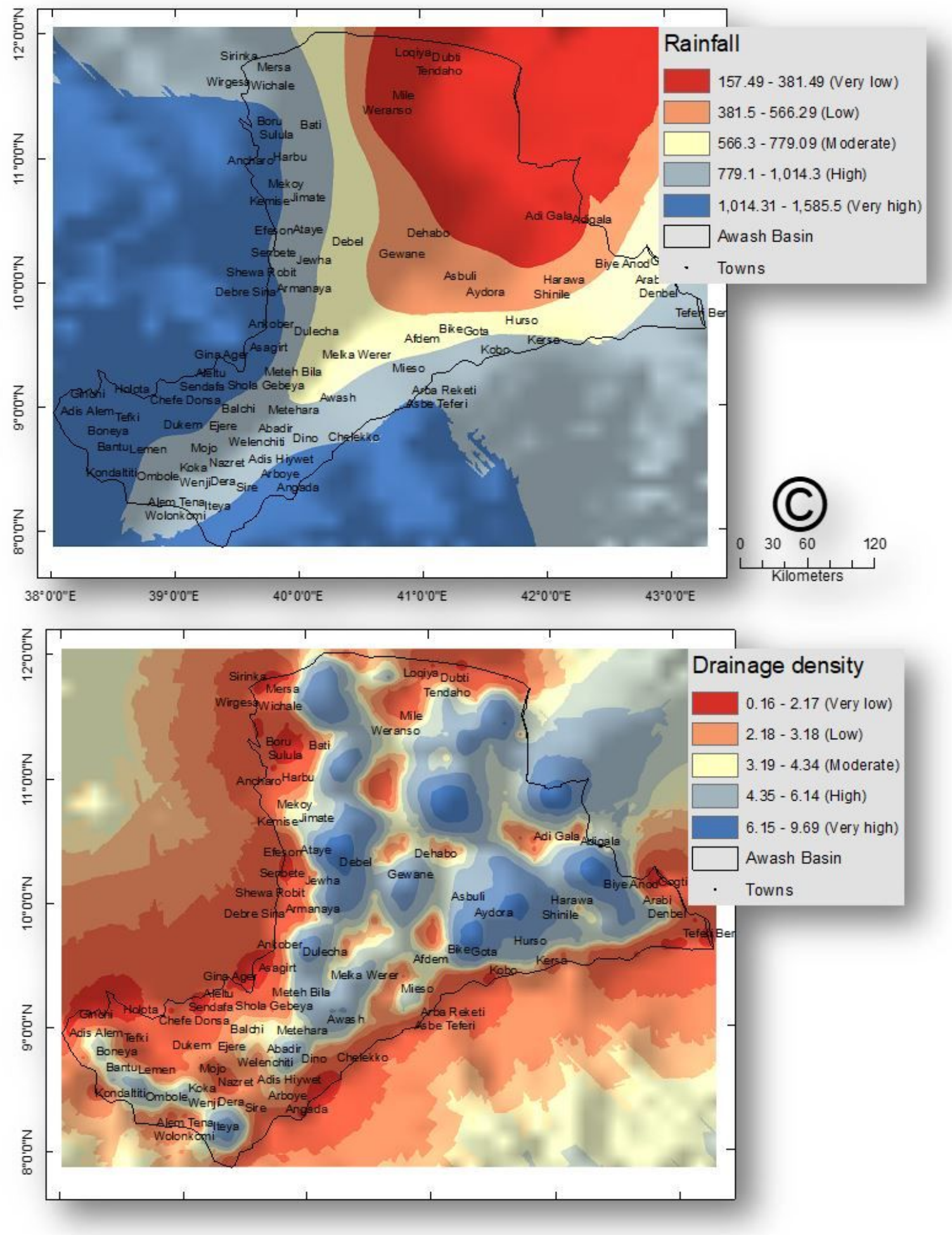

\section{Figure 4}

Weighted layers of Rainfall $(\mathrm{mm})$ and Drainage density $(\mathrm{km} / \mathrm{km} 2)$ of the Awash basin, Ethiopia Note: The designations employed and the presentation of the material on this map do not imply the expression of any opinion whatsoever on the part of Research Square concerning the legal status of any country, territory, city 
or area or of its authorities, or concerning the delimitation of its frontiers or boundaries. This map has been provided by the authors.
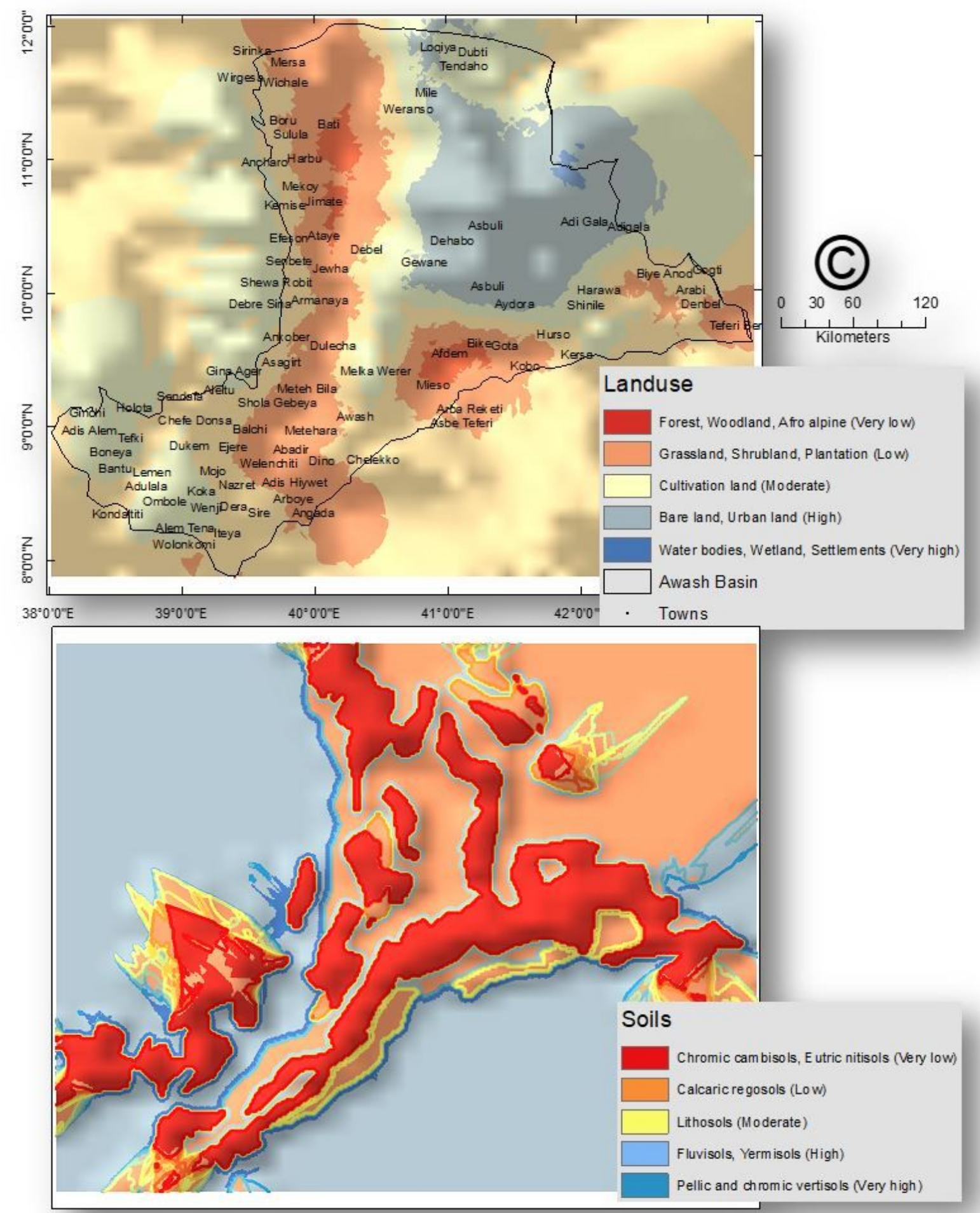

\section{Figure 5}

Weighted landuse and soils of the Awash basin, Ethiopia Note: The designations employed and the presentation of the material on this map do not imply the expression of any opinion whatsoever on the part of Research Square concerning the legal status of any country, territory, city or area or of its authorities, or concerning the delimitation of its frontiers or boundaries. This map has been provided by the authors. 


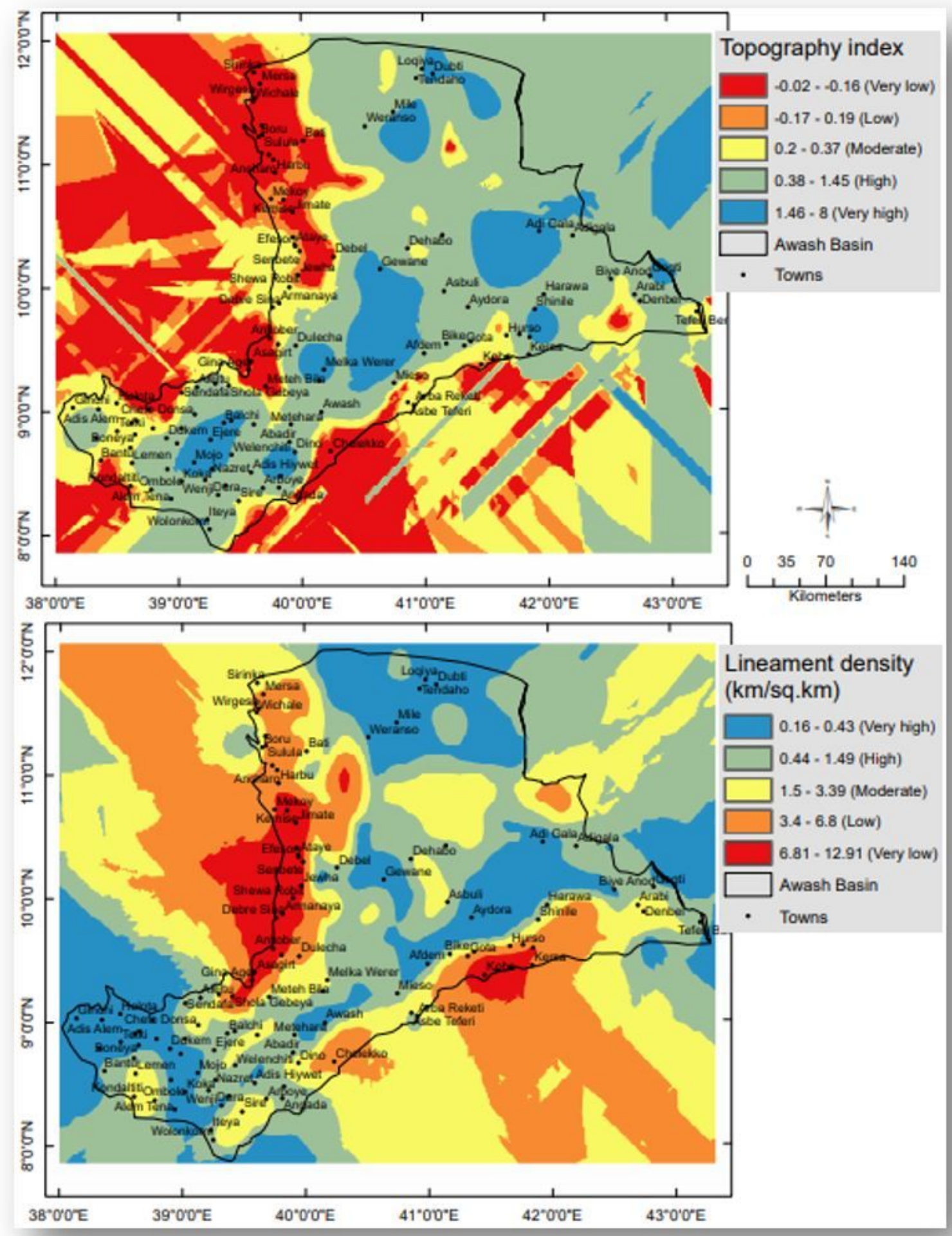

\section{Figure 6}

Weighted topographic wetness index and lineament density of the Awash basin, Ethiopia Note: The designations employed and the presentation of the material on this map do not imply the expression of any opinion whatsoever on the part of Research Square concerning the legal status of any country, territory, city or area or of its authorities, or concerning the delimitation of its frontiers or boundaries. This map has been provided by the authors. 

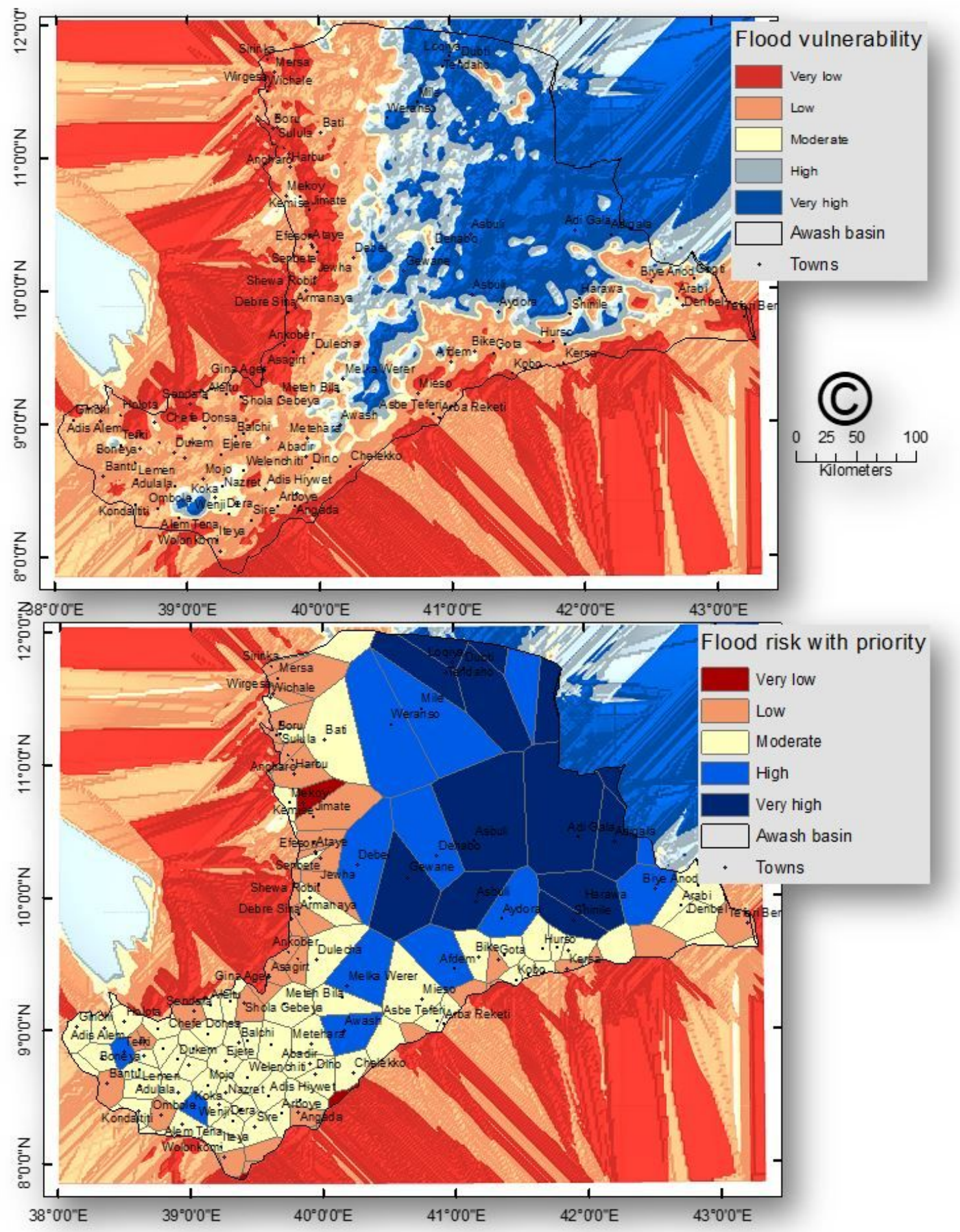

Figure 7

Spatial distribution of flood vulnerability and flood risk map of the Awash basin, Ethiopia Note: The designations employed and the presentation of the material on this map do not imply the expression of any opinion whatsoever on the part of Research Square concerning the legal status of any country, territory, city or area or of its authorities, or concerning the delimitation of its frontiers or boundaries. This map has been provided by the authors. 

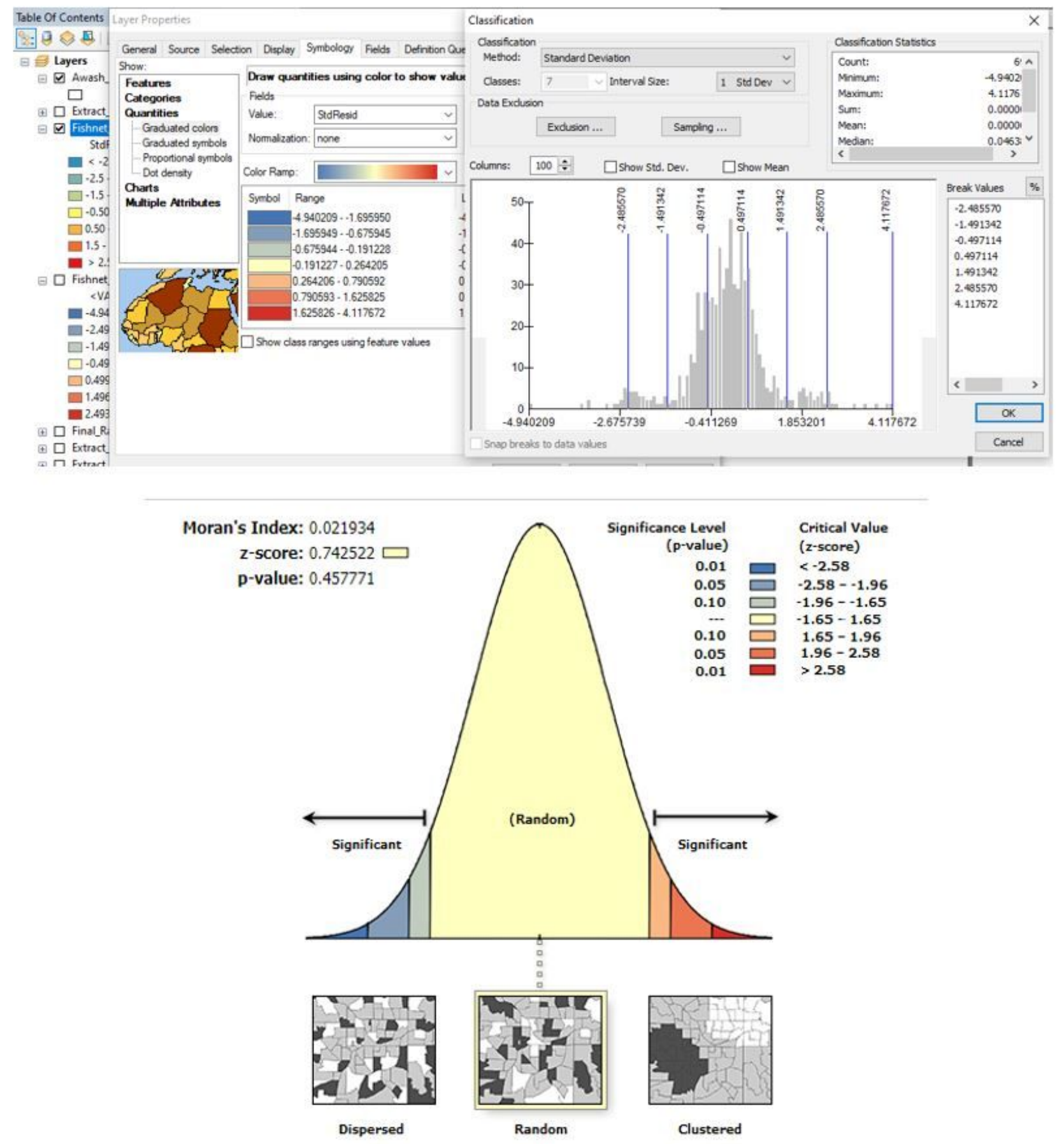

Given the z-score of 0.742522095185 , the pattern does not appear to be significantly different than random.

\section{Figure 8}

Distribution of standard residuals of explanatory regression 